\title{
22. GEOLIPIDS OF LATE CENOZOIC SEDIMENTS FROM THE WESTERN FLANK OF THE EAST PACIFIC RISE, DEEP SEA DRILLING PROJECT LEG $92^{1}$
}

\author{
Philip A. Meyers, Jerome M. Powaser, and Keith W. Dunham, The University of Michigan, Ann Arbor ${ }^{2}$
}

\begin{abstract}
Low concentrations of organic carbon in slowly accumulating sediments from Sites 597, 600, and 601 reflect a history of low marine productivity in the subtropical South Pacific since late Oligocene times. The distributions of $n$-alkanes, $n$-alkanoic acids, and $n$-alkanols provide evidence of the microbial alteration of sediment organic matter. Landderived hydrocarbons, possibly from eolian transport, dominate $n$-alkane distributions in these samples.
\end{abstract}

\section{INTRODUCTION}

The organic matter content of oceanic sediments typically is a mixture of materials from marine biota and of land-derived components. The latter materials are transported to areas of the deep sea by downslope gravity flow of sediments, by oceanic currents, and by winds. Eolian transport appears to be particularly effective in carrying fine-sized sediment components (Rea and Janecek, 1982) and particulate organic matter (Simoneit, 1977; Gagosian et al., 1981) from continental sources to oceanic areas far from land.

Because of our earlier studies in the South Atlantic, which showed major contributions of land-plant hydrocarbons to sediments from DSDP Sites 516 and 517 on the Rio Grande Rise and Sites 525 and 528 on the Walvis Ridge (Meyers and Dunham, 1983; Meyers and Keswani, 1984), we were interested in examining geolipid distributions for evidence of eolian inputs in sediments from locations where marine productivity was low and where sediment gravity flows could not contribute terrigenous material. DSDP Leg 92 obtained samples from such locations, on the western flank of the East Pacific Rise in the subtropical South Pacific (Fig. 1).

We describe in this report the distributions of aliphatic hydrocarbons, fatty acids, and fatty alcohols in sediment samples from three sites on a west-east transect under the southeast trade winds. Both solvent-extractable geolipids and those released by alkaline hydrolysis were characterized for each sample.

\section{METHODS}

Four samples of late Cenozoic nannofossil ooze were collected for this study by shipboard scientists. Site $597\left(18^{\circ} 49^{\prime} \mathrm{S}, 129^{\circ} 46^{\prime} \mathrm{W}\right)$ provided two samples. Sites $600\left(18^{\circ} 56^{\prime} \mathrm{S}, 116^{\circ} 51^{\prime} \mathrm{W}\right)$ and $601\left(18^{\circ} 55^{\prime} \mathrm{S}\right.$, $116^{\circ} 52^{\prime} \mathrm{W}$ ), about $1000 \mathrm{~km}$ from Site 597 , each provided one sample. The samples were frozen immediately after collection to preserve their organic matter contents; they were kept frozen until analysis.

The samples were freeze dried for determination of their total carbon contents with a Hewlett-Packard 185B CHN Analyzer. Residual

\footnotetext{
1 Leinen, M., Rea, D. K., et al., Init. Repts. DSDP, 92: Washington (U.S. Govt. Printing Office).

2 Address: Department of Atmospheric and Oceanic Science, The University of Michigan, Ann Arbor, MI 48109.
}

carbon was measured after $\mathrm{HCl}$ dissolution of carbonates and was considered to represent the total organic carbon content. Percent calcium carbonate was calculated from the difference between initial and residual carbon contents. Organic matter $\mathrm{C} / \mathrm{N}$ ratios were determined from residual carbon values. Percent organic carbon contents of the samples were calculated on a dry-weight basis for the original, carbonate-containing sediment.

A two-stage extraction procedure was used to obtain geolipid components from the freeze-dried sediments. Soxhlet extraction with toluene/methanol yielded the solvent-extractable fraction of materials present in the samples. A second extraction with $0.5 \mathrm{~N} \mathrm{KOH}$ in metha$\mathrm{nol} /$ toluene provided the hydrolyzeable, or bound, components. Both fractions were treated with methanolic boron trifluoride to convert fatty acids to their methyl esters, and then the geolipid subfractions were separated by column chromatography on alumina over silica gel. The subfractions so obtained contained alkanes and alkenes, aromatic hydrocarbons, fatty acid methyl esters, and hydroxy lipids, including sterols and alkanols. Hydroxy compounds were silylated with BSTFA prior to gas chromatography.

Splitless injection gas-liquid chromatography was employed to determine the types and amounts of components present in the geolipid subfractions. A Hewlett-Packard 5830 FID gas chromatograph equipped with a 20-m SE54 fused silica capillary column was used with hydrogen as carrier gas. Quantification was achieved through the use of known amounts of internal standards added to each sample before column chromatography. Individual compounds are tentatively identified by retention times in this preliminary survey. Reported values have been corrected for the small amounts of laboratory contaminants determined from blanks and for mass discrimination over the wide molecular-weight ranges surveyed.

Within a geolipid fraction, quantification is reasonably consistent, and reliable comparison can be made between samples, even though the reported quantities are quite low. No attempt was made to correlate quantifications obtained by geolipid gas chromatography with those of $\mathrm{CHN}$ analysis. Because of the small amounts of organic substances in the samples in this study, instruments were operated close to their limits of detection, and there may therefore be inaccuracies in reported concentrations.

\section{RESULTS AND DISCUSSION}

\section{Organic Carbon}

Concentrations of organic carbon in Table 1 have a mean value of $0.08 \%$ of the dry weight of these Quaternary and Tertiary sediments. These percentages are lower than the mean of $0.3 \%$ organic carbon derived from DSDP Legs 1 through 31 (McIver, 1975) and suggest low rates of marine organic matter production in overlying waters. Paleoproductivities and contributing to the organic matter present in the Leg 92 sediments can be 


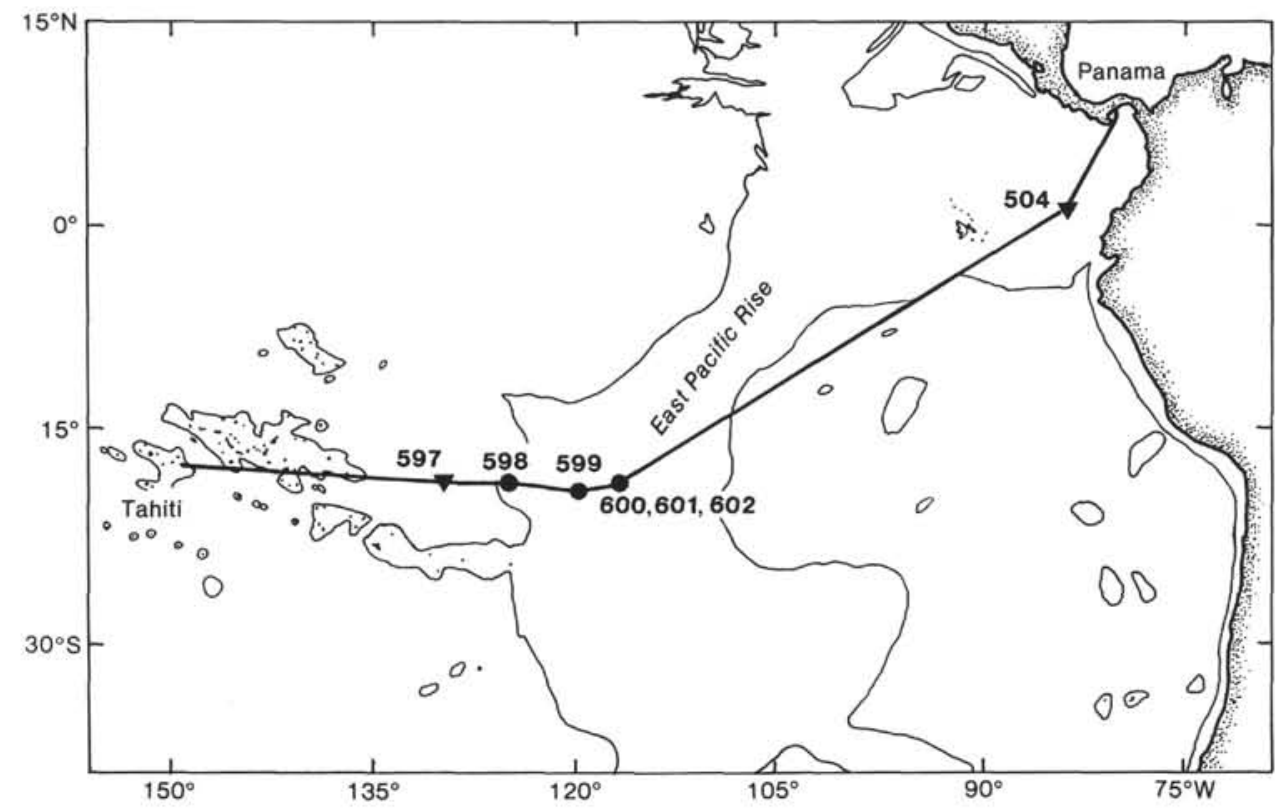

Figure 1. Locations of Sites 597, 600, and 601 in the subtropical South Pacific, shown in relation to other Leg 92 sites and the trackline of the Glomar Challenger. Inverted triangle denotes re-entry.

Table 1. Description of samples from DSDP Leg 92.

\begin{tabular}{|c|c|c|c|c|}
\hline & $\begin{array}{l}597 \mathrm{~A}-1-2, \\
86-94 \mathrm{~cm}\end{array}$ & $\begin{array}{l}597 \mathrm{~A}-4-2 \\
91-96 \mathrm{~cm}\end{array}$ & $\begin{array}{c}600-1-4 \\
40-46 \mathrm{~cm}\end{array}$ & $\begin{array}{l}601 \mathrm{~B}-1-1, \\
42-50 \mathrm{~cm}\end{array}$ \\
\hline Water depth (m) & 4163 & 4163 & 3346 & 3433 \\
\hline Sub-bottom depth (m) & 2.4 & 26.3 & 4.9 & 14.9 \\
\hline Sediment type & Clayey nannofossil ooze & Clayey nannofossil ooze & Clay-bearing nannofossil ooze & Clay-bearing nannofossil ooze \\
\hline Sediment color $^{\mathrm{a}}$ & 10 YR $7 / 4$ (very pale brown) & 10 YR $4 / 3$ (dark brown) & 10 YR $7 / 4$ (very pale brown) & 10 YR $3 / 3$ (dark brown) \\
\hline Age & early Miocene & late Oligocene & Pleistocene & early Pliocene \\
\hline $\mathrm{CaCO}_{3}(\%)$ & 85 & 93 & 86 & 81 \\
\hline $\mathrm{C}_{\text {organic }}(\%)$ & 0.12 & 0.02 & 0.05 & 0.12 \\
\hline
\end{tabular}

${ }^{\text {a }}$ Color of thawed samples after arriving at shore-based laboratory.

estimated from the expression given by Müller and Suess (1979):

$$
R=\frac{C \rho(1-\phi)}{0.0030 S^{0.30}}
$$

where $R$ is the paleoproductivity, $C$ is the concentration of organic carbon, $\rho$ is the sediment grain density $\left(2.7 \mathrm{~g} / \mathrm{cm}^{3}\right), \phi$ is the porosity $(0.70)$, and $S$ is the linear sedimentation rate in $\mathrm{cm} / 1000 \mathrm{yr}$. From the organic carbon values in Table 1 and sedimentation rates in the site summaries (this volume), paleoproductivities between 10 and $30 \mathrm{~g} \mathrm{C} / \mathrm{m}^{2}$ per yr. are obtained, and these low rates provide evidence of low productivity in this part of the central South Pacific since late Oligocene times.

Atomic $\mathrm{C} / \mathrm{N}$ ratios of sediment organic matter are often used to distinguish between marine and continental contributions of organic substances (cf. Premuzic et al., 1982). Sample $600-1-4,40-46 \mathrm{~cm}$, is the only one of the four in this study to contain sufficient organic nitrogen to yield a $\mathrm{C} / \mathrm{N}$ ratio. This value, 7.4 , is similar to $\mathrm{C} / \mathrm{N}$ ratios found in other organic-carbon-poor DSDP samples of Pleistocene age (Waples and Sloan, 1980; Keswani et al., 1984). Values in this neighborhood are sometimes considered indicative of marine origin (Premuzic et al., 1982), yet differences in diagenetic losses of carbon and nitrogen from organic matter result in alterations of $\mathrm{C} / \mathrm{N}$ values over time (Waples and Sloan, 1980). Because these Leg 92 sediments are rich in carbonate (Table 1), contributions of clay-sorbed nitrogen are not as important in modifying $\mathrm{C} / \mathrm{N}$ ratios as in the locations below the calcite compensation depth studied by Müller (1977).

The lack of measurable organic nitrogen in three of these samples indicates (1) a dominance of terrigenous organic matter of cellulosic nature, (2) an extensive loss of nitrogenous material as a result of microbial reworking of sediment organic matter, or (3) some combination of these two factors.

\section{Aliphatic Hydrocarbons}

Concentrations of total extractable aliphatic hydrocarbons are between 5 and 50 times greater than those of bound hydrocarbons (Table 2); similar preponderance of the extractable hydrocarbon components relative to the bound components has been seen in sediments from other DSDP sites (e.g., Meyers et al., 1984). Distributions of $n$-alkanes are dominated by long-chain components, as indicated by the $\mathrm{C} 29 / \mathrm{C} 17$ ratios in Table 2 and as shown in Figure 2. Hydrocarbons derived from land 
Table 2. Extractable and bound geolipids of late Cenozoic sediments from DSDP Leg 92.

\begin{tabular}{|c|c|c|c|c|c|c|c|c|}
\hline \multirow[b]{2}{*}{ Geolipid fraction } & \multicolumn{2}{|c|}{$\begin{array}{l}597 \mathrm{~A}-1-2 \\
86-94 \mathrm{~cm}\end{array}$} & \multicolumn{2}{|c|}{$\begin{array}{l}597 \mathrm{~A}-4-2 \\
91-96 \mathrm{~cm}\end{array}$} & \multicolumn{2}{|c|}{$\begin{array}{c}600-1-4 \\
40-46 \mathrm{~cm}\end{array}$} & \multicolumn{2}{|c|}{$\begin{array}{l}601 \mathrm{~B}-1-1, \\
42-50 \mathrm{~cm}\end{array}$} \\
\hline & Extractable & Bound & Extractable & Bound & Extractable & Bound & Extractable & Bound \\
\hline \multicolumn{9}{|l|}{ Aliphatic hydrocarbons } \\
\hline Total $(\mu \mathrm{g} / \mathrm{g})$ & 3.5 & 0.2 & 3.6 & 0.4 & 2.1 & 0.4 & 10.9 & 0.2 \\
\hline $\mathrm{n}-\mathrm{C} 29 / \mathrm{n}-\mathrm{C} 17$ & 8.1 & 9.5 & 5.9 & n.d. & 10.8 & 5.1 & 7.1 & 18.5 \\
\hline Pristane/phytane & 0.79 & n.d. & 0.46 & n.d. & 1.5 & 0.88 & 1.0 & n.d. \\
\hline Odd/even n-alkanes (16-33) & 1.26 & 1.08 & 1.24 & 1.08 & 1.23 & 1.11 & 0.95 & 0.95 \\
\hline \multicolumn{9}{|l|}{ Fatty acids } \\
\hline Total $(\mu \mathrm{g} / \mathrm{g})$ & 112.8 & 19.6 & 49.5 & 30.0 & 72.7 & 186.1 & 47.8 & 25.1 \\
\hline $\mathrm{n}-\mathrm{C} 26 / \mathrm{n}-\mathrm{C} 16$ & 0.13 & 0.10 & 0.05 & 0.20 & 0.11 & 0.17 & 0.09 & 0.16 \\
\hline \multicolumn{9}{|l|}{ Fatty alcohols } \\
\hline Total $(\mu \mathrm{g} / \mathrm{g})$ & 45.7 & 35.5 & 39.2 & 27.2 & 141.3 & 47.6 & 158.5 & 22.3 \\
\hline $\mathrm{n}-\mathrm{C} 26 / \mathrm{n}-\mathrm{C} 16$ & 3.9 & 0.46 & 3.1 & 0.18 & 4.3 & 0.24 & 4.9 & 0.14 \\
\hline
\end{tabular}

Note: $\mathrm{n} . \mathrm{d}$. = not determinable owing to the absence of one or both components of ratio.
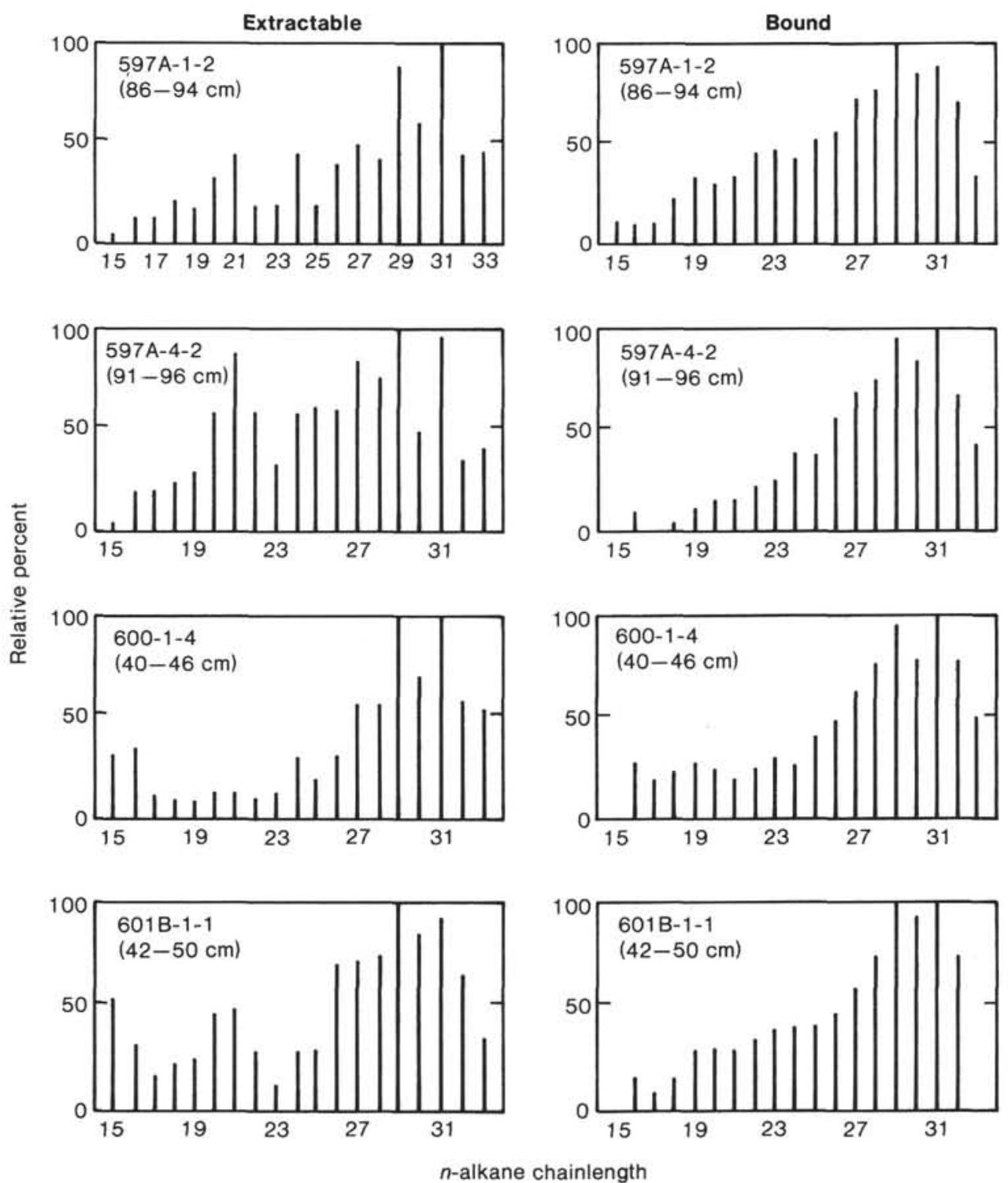

Figure 2. Histograms of extractable and bound $n$-alkanes of Leg 92 late Cenozoic nannoplankton oozes. Relative weight percents of each component are normalized to the major component $(100 \%)$ in each distribution. 
plants have $n$-alkane distributions in which C27, C29, and C31 components dominate, whereas the distributions from marine algae contain mostly shorter-chain $n$-alkanes ranging from C15 to C21 (Simoneit, 1978). Although small fractions of algal contributions are present, the $n$-alkane distributions in Figure 2 contain large amounts of land-plant components and are dominated by $\mathrm{C} 29$ or $\mathrm{C} 31$. The extractable and bound distributions give generally similar patterns despite representing very different concentrations of hydrocarbons. This similarity suggests that both fractions of the $n$-alkane portion of the aliphatic hydrocarbons have a common source.

In addition to their difference in concentrations, the extractable and bound hydrocarbons also differed in the comparative sizes of their unresolved complex mixtures (UCMs). Extractable fractions had large UCMs, as shown in Figure 3 for Pliocene Sample 601B-1-1, 42-50 cm, whereas bound fractions had small or absent UCMs. A similar contrast exists in Quaternary organic-carbon-lean samples collected from the western South Atlantic during DSDP Leg 72 (Meyers and Dunham, 1983). None of the UCMs resembled those of possible shipboard contaminants (cf. Doran and Johnson, 1979), and they varied in size and shape between the four extractable hydrocarbon fractions. These observations lead us to believe that the UCMs in these samples indicate the presence of detrital and microbially reworked organic matter and not contamination from petroleum hydrocarbons.

Further evidence of diagenetic or microbial alterations of hydrocarbons is contained in ratios of various geolipid components in Table 2. Pristane/phytane ratios range from 0.46 to 1.5 in the extractable hydrocarbons and average 0.94 ; the absence of measurable bound pristane precludes calculation of this ratio in the bound fractions. Although pristane/phytane ratios lower than 1 have been interpreted as indicators of anoxic depositional conditions (Welte and Waples, 1973; Didyk et al., 1978), the activity of methanogenic bacteria, which contain major amounts of phytane (Brassell et al., 1981; Risatti et al., 1984), evidently depresses pristane/phytane ratios regardless of the initial sedimentary setting. The combination of low pristane/phytane values and relatively low odd/ even $n$-alkane ratios (mean values 1.17 extractable and 1.06 bound) shows a dominance of reworked, detrital hydrocarbons in these Leg 92 sediments. As a consequence of the postulated microbial reworking, it appears that algal hydrocarbons have been largely replaced by microbial $n$-alkanes in the C16 to C22 range and that terrigenous components have been less affected, although the generally low odd/even dominance indicates substantial loss of original biogenic character.

\section{Fatty Acids}

The concentrations of total fatty acids in Table 2 are one or two orders of magnitude greater than those of the hydrocarbons of corresponding samples. Extractable acids are at higher concentrations than bound acids in three of the four samples, but the difference in concentrations of these two fractions is not as great as for the hydrocarbon fractions. The presence of the acidic functional group evidently provides more opportunity for these geolipids to become incorporated into non-extractable forms.

Fatty acid distributions are dominated by $n$-C16 in all fractions shown in Figure 4, although important amounts of $\mathrm{C} 24, \mathrm{C} 26$, and C28 $n$-alkanoic acids are present and indicate contributions from terrigenous plant waxes (cf. Simoneit, 1978). All fatty acid distributions have strong even-over-odd predominances, indicating a biogenic character. Extractable and bound fractions have similar dis-

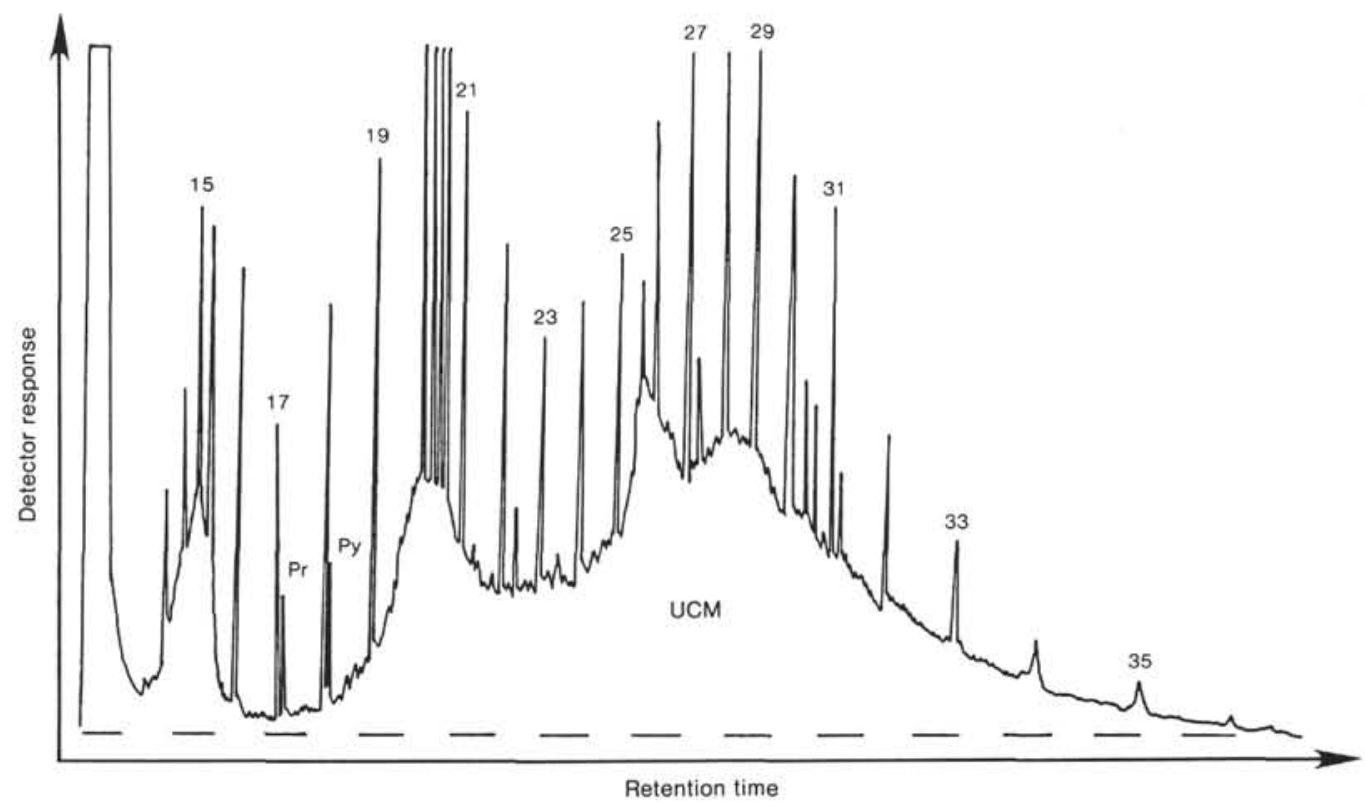

Figure 3. Chromatogram trace of extractable aliphatic hydrocarbons from Sample 601B-1-1, 42-50 cm, showing the unresolved complex mixture (UCM). $\mathrm{N}$-alkanes are identified by their carbon numbers; $\mathrm{Pr}$ identifies pristane, and Py identifies phytane. 

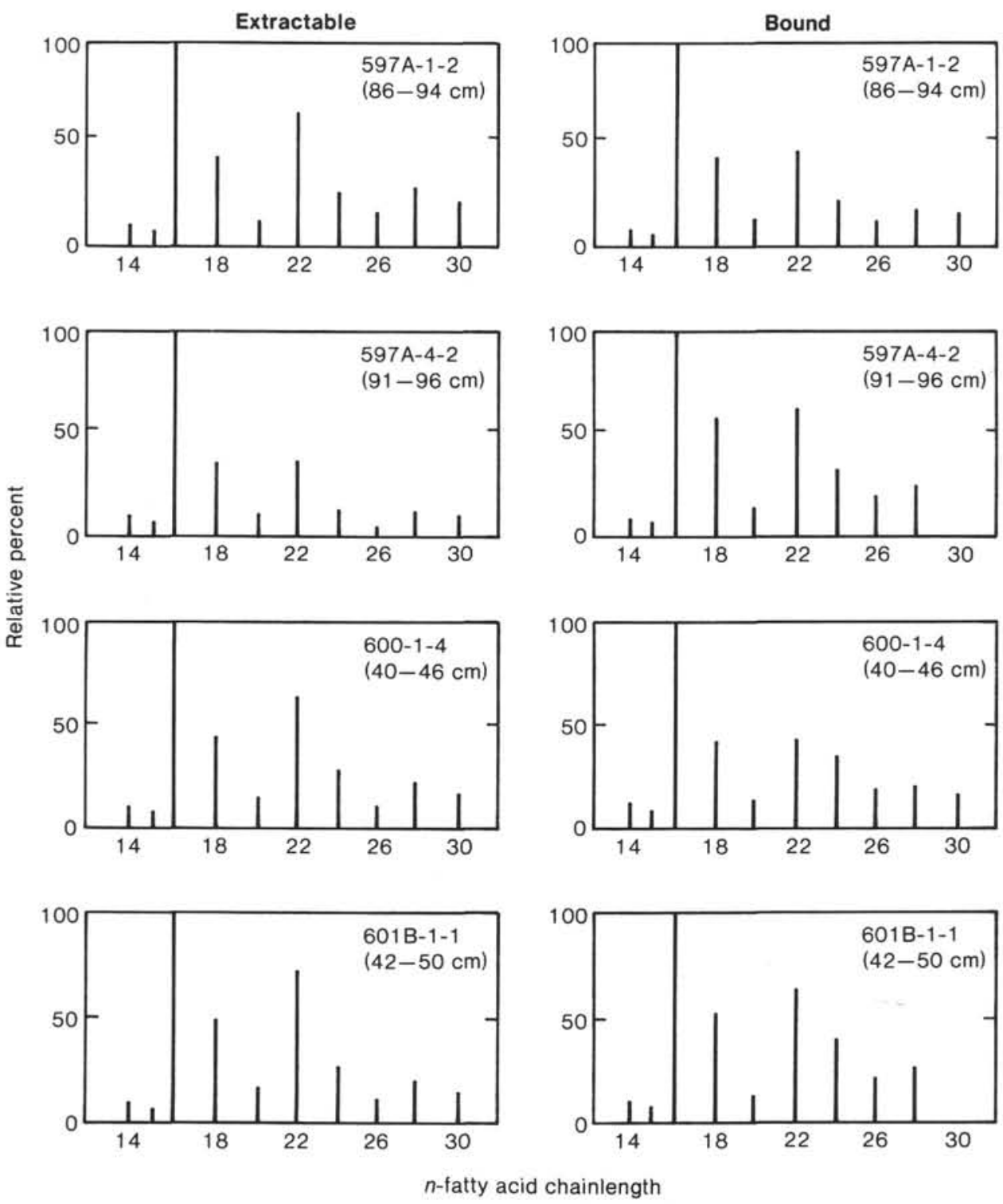

Figure 4. Histograms of extractable and bound $n$-alkanoic acids of Leg 92 late Cenozoic nannoplankton oozes. Relative weight percents of each component are normalized to the major component $(100 \%)$ in each distribution.

tributions, unlike samples from Leg 56 (Brassell et al., 1980), Leg 72 (Meyers and Dunham, 1983), or Leg 75 (Meyers and Dunham, 1984). In these other examples, fatty acids from sediments having $1 \%$ or more organic carbon (Legs 56 and 75) contain major contributions of terrigenous components in their extractable fractions and of $n$-C16 in their bound fractions. In sediments where the organic carbon levels are less than $0.5 \%$ (Leg 72), the extractable acid distributions resemble those in Figure 4 , but the bound acids often contain major amounts of long-chain components. The uniformity found between the extractable and bound $n$-alkanoic acid distributions of these organic-carbon-poor Leg 92 samples may again reflect extensive microbial reworking of sediment organic matter and resulting loss of most of its original character. The presence of long-chain components may result from preferential destruction of shorter $n$-acids (cf. Cranwell, 1981) and concomitant exaggera- tion of the terrigenous contribution, or it may indicate a more recent addition of terrigenous components to these sediments.

\section{Fatty Alcohols}

Extractable fatty alcohols have higher concentrations than their corresponding bound fractions (Table 2), but the differences between the fractions are not as large as seen in aliphatic hydrocarbons. Total concentrations of the alcohols are about the same as total fatty acids and substantially greater than those of hydrocarbons.

As shown in Figure 5, $n$-alkanol distributions are dominated by $\mathrm{C} 22$ in all of the extractable bound fractions except Sample 600-1-4, 40-46 cm, where C28 is the major component. Distributions similarly dominated by $n$-C22 have been found in organic-carbon-poor sediments from Legs 72 and 74 (Meyers and Dunham, 1983; Meyers and Keswani; 1984) and may result from postdeposi- 

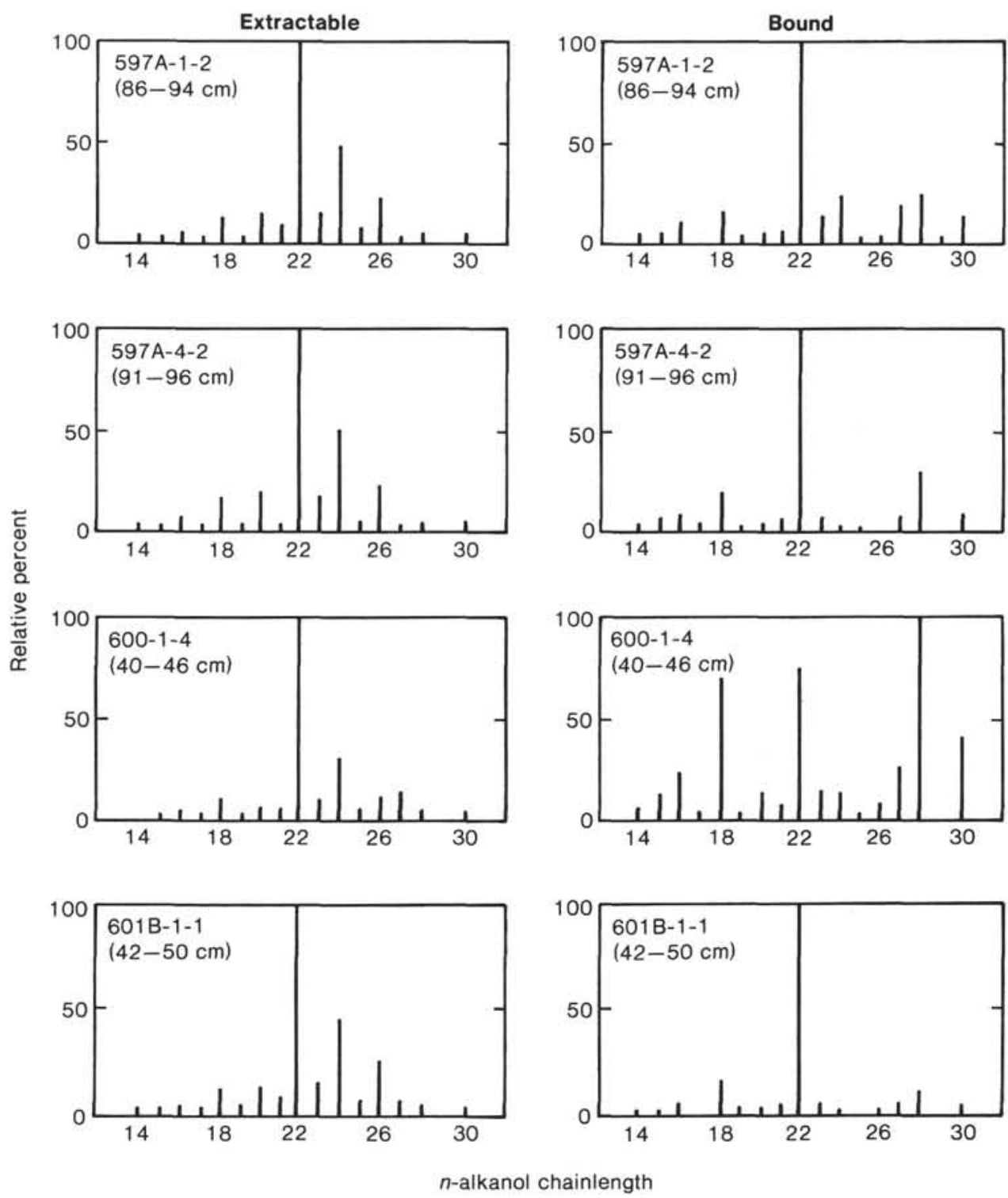

Figure 5. Histograms of extractable and bound $n$-alkanols of Leg 92 late Cenozoic nannoplankton oozes. Relative weight percents of each component are normalized to the major component $(100 \%)$ in each distribution.

tional microbial reworking of sedimentary organic matter (Cranwell, 1981). In DSDP samples having $1 \%$ or more of organic carbon, terrigenous $\mathrm{C} 24, \mathrm{C} 26$, and $\mathrm{C} 28$ $n$-alkanols are often the major components (cf. Keswani et al., 1984) as a result of overall better preservation of organic matter. The general dominance of $n$-C22 is consistent with other indicators of microbial alteration of geolipids in these Leg 92 sediments. All of the $n$-alkanol distributions in Figure 5 have strong even-over-odd predominances because of the overwhelming influence of one or two even-chain length alcohols.

\section{Evidence of Eolian Inputs}

Two types of evidence were used to determine the importance of eolian input of organic matter to late Cenozoic Leg 92 sediments. The first of these was the mass accumulation rate (MAR) of the clay size fraction and of the sediment organic carbon, and the second was the terrigenous character of the geolipid fraction of the total organic matter content of the sediments.

The MARs of the clay size fractions of the four samples we examined are extremely low (Table 3 ). Because the procedure of Rea and Janecek (1982) was used, these

Table 3. Mass accumulation rates of sediment components of samples from DSDP Leg 92.

\begin{tabular}{lcccc}
\hline & $\begin{array}{c}597 \mathrm{~A}-1-2, \\
6-94 \mathrm{~cm}\end{array}$ & $\begin{array}{c}597 \mathrm{~A}-4-2, \\
1-96 \mathrm{~cm}\end{array}$ & $\begin{array}{c}600-1-4, \\
0-46 \mathrm{~cm}\end{array}$ & $\begin{array}{c}601 \mathrm{~B}-1-1, \\
2-50 \mathrm{~cm}\end{array}$ \\
Component & Mass accumulation rate $\left(\mathrm{mg} /\left[\mathrm{cm}^{2} \times 10^{3} \mathrm{yr}\right]\right)$ \\
\hline Bulk sediment $^{\mathrm{a}}$ & 78 & 311 & 761 & 917 \\
Clay fraction $^{\mathrm{a}}$ & 2.0 & 1.5 & 1.1 & 2.6 \\
Organic carbon $^{2}$ & 0.09 & 0.06 & 0.38 & 1.10 \\
\hline
\end{tabular}


rates are for the total eolian component and not of quartz alone. In our study of South Atlantic subtropical sites (Keswani et al., 1984), we found that locations receiving hemipelagic sediments in basins and along ocean margins have clay MARs several orders of magnitude larger than those in Table 3. The low values, combined with their locations on the western flank of the East Pacific Rise, rule out downslope transport of these sediment compositions from continental sources.

Organic carbon MARs were calculated from the bulk MAR and the percent organic carbon of each sample. Largely because of the low concentrations of organic carbon (Table 1), these MARs are very low, reflecting low rates of biological productivity in overlying surface waters and substantial microbial reworking and destruction of organic materials during and after incorporation in the sea bottom at these sites.

Although the $n$-alkanoic acid and $n$-alkanol distributions in Figures 4 and 5 suggest autochthonous origins of these geolipid fractions, the $n$-alkane distributions (Fig. 2) show major inputs of land-plant material. It is clear from the hydrocarbon data that organic matter reaches these open-ocean locations from continental sources. It is likely that airborne particles transported from South America by the southeast trade winds carry organic matter that contributes to the terrigenous hydrocarbon signatures of these sediment samples. It is also probable that oceanic circulation brings land-derived organic materials to these locations in association with fine-sized particles. The relative importance of these two means of transport cannot be decided from our data, but we intuitively feel that the eolian input is the more significant contribution, particularly because the total amount of organic matter carried to these oceanic locations is small.

\section{SUMMARY AND CONCLUSIONS}

1. Low concentrations of organic carbon in late Cenozoic sediments from the western flank of the East $\mathrm{Pa}$ cific Rise indicate a history of low biological productivity since Oligocene times at these subtropical South $\mathrm{Pa}$ cific locations.

2. Distributions of $n$-alkanes, $n$-alkanoic acids, and $n$-alkanols suggest inputs of geolipids to the sediments from continental sources and subsequent microbial reworking.

3. Eolian transport is likely to have contributed to organic matter content of these deep-ocean sediments.

\section{ACKNOWLEDGMENTS}

The samples used in this study were provided through the assistance of the National Science Foundation. We thank B. R. Simoneit and E. S. Van Vleet for their reviews of this paper, and we are grateful to Ken Bloomstine and Dave Rea for providing their mass accumulation rate data. Research support was provided by NSF Grant OCE 8214605 .

\section{REFERENCES}

Brassell, S. C., Comet, P. A., Eglinton, G., Isaacson, P. J., McEvoy, J., Maxwell, J. R., Thomson, I. D., Tibbetts, P. J. C., and Volkman, J. K., 1980. Preliminary lipid analyses of Sections 440A-7-6, 440B-3-5, 440B-8-4, 440B-68-2, and 436-11-4: Legs 56 and 57, Deep
Sea Drilling Project. In Scientific Party, Init. Repts. DSDP, Vols. 56, 57, Pt. 2: Washington, D.C. (U.S. Govt. Printing Office), $1367-1390$.

Brassell, S. C., Wardroper, A. M. K., Thomson I. D., Maxwell, J. R., and Eglinton, G., 1981. Specific acyclic isoprenoids as biological markers of methanogenic bacteria in marine sediments. Nature (London), 290:693-696.

Cranwell, P. A., 1981. Diagenesis of free and bound lipids in terrestrial detritus deposited in a lacustrine sediment. Org. Geochem., 3: 79-89.

Didyk, B. M., Simoneit, B. R. T., Brassell, S. C., and Eglinton, G., 1978. Organic geochemical indicators of palaeoenvironmental conditions of sedimentation. Nature (London), 272:216-222.

Doran, T., and Johnson, P. G., 1979. Examination of potential geochemical contaminants in Leg 48 material. In Montadert, L., Roberts, D. G., et al., Init. Repts. DSDP, 48: Washington (U.S. Govt. Printing Office), 1157-1160.

Gagosian, R. B., Peltzer, E. T., and Zafiriou, O. C., 1981. Atmospheric transport of continentally derived lipids to the tropical North Pacific. Nature (London), 291:312-314.

Keswani, S. R., Dunham, K. W., and Meyers, P. A., 1984. Organic geochemistry of late Cenozoic sediments from the subtropical South Atlantic Ocean. Mar. Geol., 59:25-42.

McIver, R., 1975. Hydrocarbon occurrences from JOIDES Deep Sea Drilling Project. Proc. World Pet. Congr. 9 1975, pp. 269-280.

Meyers, P. A., and Dunham, K. W., 1983. Organic geochemistry of Quaternary sediments from DSDP Leg 72, South Atlantic Ocean. In Barker, P. F., Carlson, R. L., Johnson, D. A., et al., Init. Repts. DSDP, 72: Washington (U.S. Govt. Printing Office), 833-839. 1984. Geolipid comparison of biogenic sediments from Deep Sea Drilling Project Holes 530B, Angola Basin, and 532, Walvis Ridge. In Hay, W. W., Sibuet, J.-C., et al., Init. Repts. DSDP, 75: Washington (U.S. Govt. Printing Office), 1089-1095.

Meyers, P. A., and Keswani, S. R., 1984. Organic geochemistry of Neogene sediments from the Walvis Ridge, Deep Sea Drilling Project Leg 74. In Moore, T. C., Jr., Rabinowitz, P. D., et al., Init. Repts. DSDP, 74: Washington (U.S. Govt. Printing Office), 731-736.

Meyers, P. A., Trull, T. W., and Kawka, O. E., 1984. Organic geochemical comparison of Cretaceous green and black claystones from Hole 530A in Angola Basin. In Hay, W. W., Sibuet, J.-C., et al., Init. Repts. DSDP, 75: Washington (U.S. Govt. Printing Office), 1009-1018.

Müller, P. J., 1977. C/N ratios in Pacific deep-sea sediments: effects of inorganic ammonium and organic nitrogen compounds sorbed by clays. Geochem. Cosmochim. Acta., 41:765-776.

Müller, P. J., and Suess, E., 1979. Productivity sedimentation rate, and sedimentary organic matter in the oceans-I. Organic carbon preservation. Deep Sea Res., 26A:1347-1362.

Premuzic, E. T., Benkovitz, C. M., Gaffney, J. S., and Walsh, J. J., 1982. The nature and distribution of organic matter in the surface sediments of world oceans and seas. Org. Geochem., 4:63-77.

Rea, D. K., and Janecek, T. R., 1982. Late Cenozoic changes in atmospheric circulation deduced from North Pacific eolian sediments. Mar. Geol., 49:149-167.

Risatti, J. B., Rowland, S. J., Yon, D., and Maxwell, J. R., 1984. Stereochemical studies of acyclic isoprenoids-XII. Lipids of methanogenic bacteria and possible contributions to sediments. Org. Geochem., 6:93-104.

Simoneit, B. R. T., 1977. Organic matter in eolian dusts over the Atlantic Ocean. Mar. Chem., 5:443-464.

1978. The organic geochemistry of marine sediments. In Riley, J. P., and Chester, R. (Eds.), Chemical Oceanography (Vol. 7): London (Academic Press), 233-311.

Waples, D. W., and Sloan, J. R., 1980. Carbon and nitrogen diagenesis in deep sea sediments. Geochim. Cosmochim. Acta, 44:14631470.

Welte, D. H., and Waples, D. W., 1973. Über die Bevorzugung geradzahliger $n$-Alkane in Sedimentgesteinen. Naturwiss., 60:516-517.

Date of Initial Receipt: 10 July 1984

Date of Acceptance: 26 December 1984 